International Journal of English Literature and Social Sciences
Vol-6, Issue-5; Sep-Oct, 2021

Peer-Reviewed Journal

\title{
The Self-Actualized Protagonists in Paulo Coehlo's The Alchemist and Eleven Minutes
}

\author{
Dr. Clara Bernadette Reshma ${ }^{1}$, Fr Bibin $\mathrm{J}^{2}$
}

${ }^{1}$ Asst Professor of English, Fatima Mata National College (Autonomous), Kollam-691001, India
${ }^{2}$ Research Scholar, PG \& Research Dept. of English, Fatima Mata National College (Autonomous), Kollam-691001, India

Received: 25 Sep 2021; Received in revised form: 23 Oct 2021; Accepted: 27 Oct 2021; Available online: 31 Oct 2021

(C)2021 The Author(s). Published by Infogain Publication. This is an open access article under the CC BY license

(https://creativecommons.org/licenses/by/4.0/).

\begin{abstract}
Man, since time immemorial is in continual search for the essential quest of meaning and the ultimate reality of life which comes through self-actualization. Self-actualization is the basic need, the ultimate goal and a continual process of growth for human beings. Paulo Coelho, a Brazilian novelist, takes the human self as the central point to deal with the wider issues of the human enterprise. In his fictional world common human beings, not the epic heroes/heroines struggle to try to find the true meaning of life. His heroes are not defeated and heart broken by the bitter realities of life, but are the ones who take arms against all the oddities that life offers and resort to noble and seldom trodden paths in order to pursue and find treasures that lie un-explored within the human self. The present paper seeks to explore the selfactualized heroes of the two protagonists' Santiago and Maria in his novels Alchemist and Eleven Minutes and provide us lessons on how to find the purpose and meaning of life.
\end{abstract}

Keywords - Self, Dreams, Displacement, Love, Transformation, Self-actualization.

In the present epoch that man lives in, his dreams and aspirations are thwarted with questions pertaining to himself and with limitations placed by society, laws, mores, customs, traditions, family, and even self-perception that make him give up the great possibilities that lie a he ad of $\mathrm{him} /$ her. To unleash the potential within oneself is no mean task. Literary works, especially fiction act as an explanation to many of the contemporary social and psychological crisis that postmodern man finds difficult to cope with. Everything that happens within society, of which man is considered the core factor, can be written, recorded in, and learned from literature. One such present day crisis is that man/woman has lost sight of their self in today's fastchanging global world. He/she has abandoned the essential quest for meaning and the ultimate reality of life which comes through self-actualization.

In order to attain self-realization, a person hasto manifest the contents of his unconscious state into the conscious state, for the unconscious and the conscious are opposites; however, they are at the same time complementary. The unconscious is divided into two: the personal and the collective unconscious. The collective unconscious is composed of archetypes, autonomous instincts, patterns, or behaviors which encompass time, places, and people. Since the unconscious state exercises great power, gaining subtle control, collective unconscious can perform great miracles-one of which is self-realization.

Paulo Coelho, a Brazilian novelist, takes the human self as the central point to deal with the wider issues of human enterprise. The self in his works comprise the many facets of self. In his fictional world common human beings, not the epic heroes/heroines struggle to try to find the true meaning of life. His heroes are not defeated and heart broken by the bitter realities, but are the ones who take arms against all the oddities that life offers and resort to noble and seldom trodden paths in order to pursue and find treasures that lie un-explored within the human self. Every book of Paulo Coelho presents a journey or a search for a way of life that enriches the meaning of existence. It also brings a message of hope. A man's life is considered successful when he 
fights and struggles and emerges victorious and his greatest asset is the wisdom acquired in this process.

The central protagonists of the novels, The Alchemist and Eleven Minutes, are ordinary human beings but epitomes of exceptional qualities. Their empirical experiences from those of ordinary human beings to self-actualized ones reveals to all of us significant lessons of courage, determination and single-mindedness required to achieve glorious triumphs in the journey of life. This study uncovers that these novels portray not only the literal journey of the characters but also reflects the journey towards selfactualization accomplished through spiritual enlightenment and dream-realization.

The two novels under study The Alchemist and Eleven Minutes could be decoded from various theoriesphilosophical, allegorical and existential, encompassing several meanings underneath the surface meaning. On the surface level, they seem a simple tale of struggle, of love and exploration, but by unlocking its allegorical threads one comes to the realization that they are both works of fiction that narrate those realties which are no less than poetic revelations. Each word, every sentence and each page of the book deserves thorough attention because it is pregnant with poignant meanings.

A comparison of the self-actualized protagonist of the novels The Alchemist and Eleven Minutes is the focus of this study. The lives of the novel's central protagonists, Santiago and Maria, fundamentally reflect the traits and dispositions of self-actualized persons. The factors and elements that propel these protagonists in their journey towards self-actualization are dreams(aspiration), physical journey (displacement), love and transformation.

Dreams in the sense of goals or aspirations constitute a major characteristic of the protagonists. Santiago's dream of the treasure provided him with a goal; he resolved to find the treasure, and by his decision to pursue his goal, ultimately, he was able to realize his personal legend "And, when you want something, the entire universe conspires in helping you to achieve it" (The Alchemist 21). While Maria's dream took her not only to a faraway country but also to a career and exposed her to different levels of love which she could never have experienced in her small Brazilian town. Initially, the desire for love takes shape in Maria's girlhood dreams of finding the right man to marry and raise a family:

She dreamed of meeting the man of her life (rich, handsome, intelligent), of getting married (in a wedding dress), having two children (who would grow up to be famous) and living in a lovely house (with a sea view). (Eleven Minutes 1 )
The desire and the passion inherent in these protagonists led them to new pastures where they could accomplish self-actualization. Overcoming all obstacles and hardships, Santiago, the main character of the novel, The Alchemist, took up a journey from Spain to Egypt. He finds out that he must travel to Egypt in order to fully understand what his psyche is trying to tell him. Maria, a young girl from a remote village of Brazil moved out from her native place to seek her fortune in Switzerland and "She then decides to become a prostitute and ends up in a brothel on Rue de Berne, the heart of Geneva's Red-Light District".

The very first step of every Self-actualization process is moving out of the existing and continuing physical settings and atmosphere. Analyzing the biography of every enlightened man, one finds that there is an inner urge that forces these individuals to move away from their home. Adi Shankara, Bodidharama, Buddha etc. left their homes and comfort zones in order to search for the ultimate meaning of life.

In The Alchemist, a Spanish shepherd named Santiago searches for the meaning of his dreams. Overcoming all his obstacles and hardships, Santiago, the main character of the novel, takes up a journey from Spain to Egypt. He finds out that he must travel to Egypt in order to fully understand what his psyche is trying to tell him. Ultimately, he is told that a great treasure awaits him. However, "while he expects gold and physical wealth, he arrives in Egypt and meets an Alchemist who tells him that the real wealth lies in fulfilling a Personal Legend, or what a person has always longed to do" (Oglesby). In many ways, the story benefits from being told across a continuum of culture that links southern Spain and Egypt.

In Eleven Minutes, in order to achieve her aspirations and dreams Maria moves her locale of residence, from Brazil to Switzerland. Maria, a young girl from a remote village of Brazil, whose first encounters with love had left her heartbroken, goes to seek her fortune in Switzerland. She works for a time in a nightclub but soon becomes dissatisfied and after a heated discussion with her manager one night, she quits her job. She tries to become a model but is unsuccessful. Running out of money, she accepts 1000 francs from an Arab man to spend the night with him. "She then decides to become a prostitute and ends up in a brothel on Rue de Berne, the heart of Geneva's Red-Light District". The setting in Eleven Minutes happens in two countries, namely Brazil and Switzerland.

Love experiences of both the protagonists propelled them to their destiny. Santiago's expression of love is evident in his 
early confession and request for Fatima's hand in marriage. In The Alchemist, the theme of love shines through the moment Santiago lays eyes on Fatima.

At that moment, it seemed to him that time stood still... When he looked into her dark eyes, and saw that her lips were poised between a laugh and silence, he learned the most important part of the language that all the world spoke-the language that everyone on earth was capable of understanding in their heart. It was love. (88)

In Eleven Minutes, Maria dreamed of true love. She falls in love many times and with many men. She concludes from her own experience that "love is not as beautiful as she thinks" (Pramudya 28). In her teenage years, she learned about love and heartaches, and discovered the other side of sex, which actually was the commencement of her journey to finding true love. When the time was right, fate presented her true love in the form of Ralf Hart, with whom she re-discovered her lost self that was longburied in heaps of pains, failures, and activities she had engaged with hitherto. Maria wanted Raft Hart to be the last person in her life because with him, she feels complete in her life. With Raft Hart, Maria's experience combines a feeling of deep attachment and intimacy.

The transformational journey is illustratedin both the characters, of Santiago in The Alchemist and Maria in Eleven Minutes. In The Alchemist, Santiago started his journeyin order to find out the truth of his recurrent dream of the buried treasure in the Pyramids of Egypt, which was called by the wise old kin $\mathrm{g}$ Melchizedek as his personal legend. It is what one has always wanted to accomplish, which one ultimately realizes. However, in the course of his journey towards the Pyramids, his being has been transformed as well: he started to believe in personal omens or signs, learnedthe universal language of the world sometimes known as "intuition" or "hunch" and applied it in his day to day life, "The boy told himself that, on the way toward realizing his own destiny, he had learned all he needed to know, and he had experienced everything he might have dreamed of'(153); Santiago decided to trust himself as well as others, understood his heart, includingits fear and desires; recognized that everything is interconnected and is part of him, and he needed both the animate and inanimate if he isto understand his self and the world; and most importantly he learned that he is the replica of God, that is, God's spirit dwells in him and it is this that allows him to perform miracles. And finally, in his self-actualized state he comes to the realization that "now he knew where his treasure was" (155). Thus, the acme of his spiritual journey of self-actualization is finding his mission on earth, that of being able to perform miracles because of the realization that God's Spirit dwells in him.

In Eleven Minutes, Maria tries to accept the reality that the partner does not cause hurt, pain and suffering but it is her own making that causes it. Finally, she did find true love in an equally disillusioned painter Ralf Hart and he helped her to attain her soul. She discovered a whole universe inside her own body. Coelho asserts

... it wasn't eleven minutes, it was an eternity, it was as if we had both left our bodies and were walking joyfully through the gardens of paradise in understanding and friendship. I was woman and man; he was man and woman. I don't know how long it lasted, but everything seemed to be silent, at prayer, as if the universe and life had ceased to exist and become transformed into something sacred, nameless and timeless." ( 264)

By comparing the self-actualized protagonists of the novels, The Alchemist and Eleven Minutes many similar characteristics and desires can be traced- their dreams, displacement, love and transformation. The study finds out that these novels portray not only the literal journey of characters but also reflects the journey of the protagonists towards self-actualization attained through spiritual enlightenment and dream-realization. Both the protagonists face similar physical situations and undergo similar mental dispositions in their journey towards self-actualization, besides, both the protagonists' manifest similarity in selfactualized features and attributes. Self-Actualization may be loosely described as the full use and exploitation of talents, capabilities, potentialities, etc. Such people seem to be fulfilling themselves and to be doing the best that they are capable of doing. They are people who have developed or are developing to the full stature of which they capable (Mcleod). Self-Actualization is attainment of dreams and aspirations realized through indomitable will. Santiago and Maria had traversed various paths, including risky ways and painful efforts, that led to their destiny finally. This state of self-Actualization was not attained within a single day, rather, it was a journey taken up by the protagonists' who long to attain this state. In the novels The Alchemist and Eleven Minutes, the protagonists Santiago and Maria take up a journey towards self-Actualization and in this journey, they traverse through different geographical regions, give in to their intuitions, use knowledge and learning to experience heavenly bliss on earth. On a close reading of the two novels selected for study The Alchemist and Eleven Minutes 
Coelho suggests remedies that may not be of a sublime metaphysical dimension, but are convincing and easily practicable, he provides suggestions so that all human beings attain peace and prosperity.

The destination of where we want to go is often defined as a dream. one should live each day so that one gets a step closer to one's dream and destination. It is important to know and remember where you are and whom you are in order to get to where you want to be and whom you want to be. Nothing worth having ever comes easy. If you desire something with all your heart, you have to be prepared to take risks, get rid of all doubt and ignore your fears. If you think big, listen to your heart and dedicate your life to achieving whatever it may be, the universe will always reward you with attainment. The soul is a treasure and is farthest to be discovered and in the journey of its discovery one is destined to delve deep into the realms of one's innermost recesses to find the treasure. Everything that exists in the world has an entity and is supposed to aid and assist those who are out on a journey to actualize their dreams. The quest to realize one's dream begins from the pangs of the inner recesses of the heart. People often fail to respond to the beats of their hearts merely because they are immersed in a world which really does not belong to them. They are unable to recognize their innermost quest and the voice of the soul not because they are incapable of doing so, but obstacles like thoughts of impossibility, fear, love and defeat stand in the way of the pursuit of their dream. But, when the journey towards the realization of dream is set out in response to a call from within, the impossibilities are converted into bridges to success, the fear turns out to muster the courage, the defeat decides to surrender before the towers of inspiration and all the obstacles become tools to achieve what the soul really pines for. The world with its arms' wide open waits and watches, with zeal and zest to intersect the individual who is empowered to dominate the universe by breaking free of the shackles of agnosticism and nihilism.

\section{REFERENCES}

[1] Cherry, Kendra. The Everything Psychology Book: An Introductory Guide to the Science of Human Behavior. Adams Media, 2010.

[2] Coelho, Paulo, The Alchemist trans Costa, Margraet J Harper Collins Publishers, 1988.

[3] Coelho, Paulo, Eleven minutes trans Costa, Margraet J Harper Collins Publishers, 2003.

[4] D'zousa, Jeevan. "Self- Actualization in the book The SAGE Encyclopedia of Lifespan Human Development." 2018, www.researchgate.net/ publication/32411 5279
[5] Fromm, Erich. The Art of Love. Harper \& Brothers Publishers, 1956.

[6] Marika Schaerti, An Interview with Paulo Coelho. Focus Munich, 19 December 2007.

[7] Mirafuentes, J. A.et al "Human ethos of Paulo Coelho's selected novels." University of the Visayas Journal of Research, vol. 9, no. 1, 2015. pp. 171-188.

[8] Mcleod, Saul. "Maslow's Hierarchy of Needs." Simply Psychology. Taylor and Francis. www.simplypsychology.org/maslow.html

[9] Pramudya, Pascalis. "The Meaning of Love as Seen in Maria, the main character of Paulo Coelho's Eleven Minutes." Yogyakarta: English Language Education Study Program. Department of Language and Arts Education, Faculty of Teacher Training and Education, Sanata Dharma University, 2018.

[10] www. repository.usd.ac.id/32643/2/121214090.

[11] Shinde, Pradeep. "Quest for Self as Reflected in Paulo Coelho's Novel, The Alchemist." Shanlax International Journal of English, Vol. 8, 1 Mar 2020. 